\title{
On the food and feeding habit of an estuarine catfish (Mystus gulio Hamilton) in the south-west coast of Bangladesh
}

\author{
M. Begum*, M. J. Alam, M. A. Islam and H. K. Pal \\ Bangladesh Fisheries Research Institute, Brackish water Station, Paikgacha, Khulna-9280, Bangladesh ${ }^{*}$ Corresponding author \\ address: alammj_bfri@yahoo.com
}

Food is the main source of energy and plays an important role in determining the population levels, rate of growth and condition of fishes. Food and feeding habits of fishes have a great significance in aquaculture practice. It helps to select such species of fishes for culture which will utilize all the available potential food of the water bodies without any competition with one another but will live in association with other fishes. Mystus gulio (Ham.) is a native catfish of family Bagridae distributed around India to Malay Archipelago, especially estuarine and tidal waters (Jhingran, 1997). In Bangladesh, this catfish is locally known as "nuna tengra", and commonly occurring in brackishwater environment. Despite of its enormous importance in brachishwater aquaculture, the food and feeding habits of this valuable species has not been adequately studied except some observations made by Pandian (1966), Sarker et al. (2002), Alam et al. (2006a \& 2006b) and Islam et al. (2007) on the feeding and reproductive cycle, fecundity, induced spawning, spawning behavior and larvae rearing. Other workers who worked on food and feeding habits of other fishes include these of Bhuiyan (1988), Bhuiyan \& Haque (1985) and others. However, for developing culture technologies, biological studies of this species are indispensable. Therefore, this work was carried out to identify the food and feeding habits of $M$. gulio to generate the base line information for facilitating the sustainable aquaculture especially in the coastal belt of the country.

A total of 250 fishes of different size, maturity and sex groups were collected randomly from different places of Paikgacha Upazila, under Khulna district of Bangladesh during the period of September, 2005 to August, 2006. Immediately after collection the fishes were preserved in $10 \%$ formalin solution to prevent the break down of the food materials. In the laboratory, fishes were washed, cleaned and total length in mm of each fish was measured and then the qualitative and quantitative analyses of stomach contents of each fish were done by point and percentage of frequency of occurrence methods as followed by Dewan \& Shaha (1979).The different food items eaten by the fishes were identified under microscope by following the keys given by Pennak (1953), Ward \& Whipple (1959), Prescott (1962) and Needham \& Needham (1962).

To study the gut content each stomach was analyzed separately. The stomach of individual fish was cut open and removed on to petridish with the help of very fine forceps. The percentage of occurrence of a particular food item was calculated on the basis of the following formula:

Percentage of occurrence of a food type = Number of gut where the food occurred Total no. of gut analyzed

To apply the point's methods all the food items eaten by the species were identified. Then the volume of the stomach contents of each fish was estimated by observation and recorded on an absolute scale and points were allotted to each stomach according to the volume of its contents. In case of Index of fullness methods, the index of fullness of the stomach was recorded irrespective of the size of the stomach of the fish using ' 0 ' for empty; ' 1 ' for one fourth full, ' 2 ' for half full, ' 3 ' for three fourth full and ' 4 ' for full stomach.

The gut contents analyses of $M$. gulio were performed by three methods namely frequency of occurrence method, points method and index of fullness method. It is well known that no single method is adequate for analysis of stomach contents of food. The total length of the fishes ranged from $40-180 \mathrm{~mm}$.

The gut contents analysis of fishes from each size showed that the fish feed on a variety food items. The food types recorded are cladocerans (Daphnia, Ceriodaphmia, Scapholebris, Diaptomus, Moina); copepods (Cyclops), rotifers (Keratella, Brachionus, Pleurotracha), grastropods (Physa), insects (Corixa, Chironomus, Notonecta, Tubifera, Lepidoptera), diatoms (Synedra, Bacillaria, Fragillaria), green algae (Spirogyra, Closterium, Ulothrix, Cosmarium); prawns, small fishes and others which include unidentified items.

All these food organisms were categorized into 9 main food groups viz. cladocerans, copepods, rotifers, gastropods, insects, diatoms, green algae, prawn and 
small fishes and others (semi digested unidentifiable parts of plants and animals). Amongst these food groups, insect was the most dominant food item both by percentage of total points (43.25\%) and percentage of occurrence (60\%).The next preferred food items were diatoms and green algae. But the percentage occurrence of diatom (55\%) was found to be the most dominant, food group which was closely followed by green algae (45\%). Cladocerans, copepods and rotifers were recorded only in the stomach of immature and juvenile fishes. The food group prawns and small fishes, gastropods and others were recorded rarely in the stomach of the adult fish

Table 1. Diet composition of Mystus gulio based on percentage of occurrence and percentage of total points.

\begin{tabular}{|c|c|c|c|c|c|c|c|c|c|}
\hline \multirow[b]{2}{*}{ Items } & \multicolumn{9}{|c|}{ Food groups } \\
\hline & Cladocerans & Copepods & Rotifers & $\begin{array}{l}\text { Gastro } \\
\text { - pods }\end{array}$ & Insects & Diatoms & Green alage & $\begin{array}{l}\text { Prawn and } \\
\text { Small fishes }\end{array}$ & Others \\
\hline $\begin{array}{l}\text { No. of fish in } \\
\text { which occurred }\end{array}$ & 76 & 94 & 70 & 12 & 140 & 112 & 80 & 7 & 46 \\
\hline $\begin{array}{l}\text { Percentage of } \\
\text { occurrence }\end{array}$ & $7.2 \%$ & $7.8 \%$ & $5.6 \%$ & $6.0 \%$ & $60 \%$ & $55 \%$ & $45 \%$ & $12.14 \%$ & $8.14 \%$ \\
\hline $\begin{array}{l}\text { Average } \\
\text { Points/fish }\end{array}$ & 2.71 & 1.22 & 0.51 & 0.02 & 12.38 & 4.05 & 3.33 & 0.04 & 1.22 \\
\hline $\begin{array}{l}\text { Percentage of } \\
\text { total points }\end{array}$ & $4.63 \%$ & $3.05 \%$ & $3.22 \%$ & $0.14 \%$ & $43.25 \%$ & $29.63 \%$ & $12.08 \%$ & $2.60 \%$ & $1.40 \%$ \\
\hline
\end{tabular}

All the food groups showed considerable monthly variations in the gut contents of the fish (Table: 2). Among all the food groups insects was found to be the most dominant food item by average points per fish in most of the months of the year. Next to insects, diatoms, green algae, cladocerans and Copepods occupied the successive position by average point per fish. Comparatively greater amount of insects was found to occur during winter and summer months whereas diatoms and green algae was found to be most dominant during autumn months in the gut contents of the fish. The food groups such as copepods and cladocerans were recorded mostly in the gut contents of immature and juvenile fishes.

Table 2. Monthly variations in the amount of food taken by Mystus gulio based on average index of fullness and average points per fish.

\begin{tabular}{cccccc}
\hline \multirow{2}{*}{ Months } & \multicolumn{5}{c}{ Items } \\
\cline { 2 - 6 } & $\begin{array}{c}\text { No. of fish } \\
\text { examined }\end{array}$ & $\begin{array}{c}\text { No. of stomach } \\
\text { with food }\end{array}$ & $\begin{array}{c}\text { \% of empty } \\
\text { stomach }\end{array}$ & $\begin{array}{c}\text { Av. index of } \\
\text { fullness }\end{array}$ & $\begin{array}{c}\text { Av. Points } \\
\text { per fish }\end{array}$ \\
\hline September & 15 & 15 & 0 & 3.0 & 56.00 \\
October & 13 & 10 & 23.07 & 1.60 & 33.33 \\
November & 18 & 6 & 11.11 & 2.70 & 14.30 \\
December & 10 & 8 & 20.00 & 1.60 & 19.34 \\
January & 13 & 1 & 23.07 & 2.33 & 33.38 \\
February & 27 & 6 & 40.74 & 3.8 & 46.67 \\
March & 19 & 8 & 47.36 & 2.11 & 15.30 \\
April & 25 & 14 & 84.00 & 1.75 & 26.39 \\
May & 50 & 12 & 76.00 & 1.70 & 23.39 \\
June & 47 & 14 & 70.20 & 1.20 & 8.39 \\
July & 8 & 6 & 25.00 & 2.58 & 28.29 \\
August & 5 & 4 & 20.00 & 1.60 & 4.60 \\
\hline
\end{tabular}

The results of the study of the seasonal feeding patterns of fishes have been presented in table 2. It is observed that during the pre-spawning period of April to May the fish minimized its feeding rate, and later, in August again a marked rise in the feeding rate was observed. An inverse relationship between feeding and breeding cycles has been reported by many workers (Homans \& Vladykov, 1954; Pandian, 1966). Pantulu (1961) also reported a similar observation from his studies on the feeding intensity of $M$. gulio in the Hooghly estuary of India. He mentioned that, about 50$100 \%$ of the investigated M. gulio had 'empty' 
stomachs during the pre-spawning months to May and June respectively. After spawning in July, the fish fed intensively, more than $60 \%$ of the investigated fishes had either full or 'gorged' stomach. This high feeding intensity steadily decreased during the subsequent months, about $30 \%$ of the investigated fishes had hardly any food in their stomachs during December January. These findings agreed with the findings of Pandian (1966), who reported that analyses of the stomachs of the fishes collected in April revealed that more than $80 \%$ were starving, and the rest had only tracer quantities of food in the stomachs.

Reddy and Rao (1987) studied the food of M. vittatus and observed seasonal variation in the rate of feeding. They recorded no uniform pattern is discernible in the two years of study. However, in general, the maximum rate of active feeding is during December to February as was observed by Bhatt (1971a) in M. vittatus from Aligarh.

The food items in the stomach of $M$. gulio suggest that they are euryphagous (i.e. feeding on a wide range of organisms). It was also observed that $M$. gulio can be classified as an omnivorous feeder as the diet covers a wide spectrum of food ranging from various types of plankton to invertebrates and plants. The fish also exhibits an overlapping in food and feeding habits in order to avoid inter and intra specific competition for available food. This is an important strategy for survival and an advantage over the fish species competing for a specific food item. This explains the availability of $M$. gulio all the year round. Such an eryphagous feeding behaviour is documented in many of the catfishes (David, 1963; Thomas, 1966). The determination of food habit was also reported by Mustafa et al. (1980) for Nandus nandus, Bisht and Das (1981) for Puntius ticto, Cyprinus carpio, Tor tor, Nemaechilus rupicola and Channa gachua. Bhuiyan and Rahman (1983) for Channa gachua, Reddy \& Rao (1987) for $M$. vittatus, Khan et. al. (1988) for $M$. nemurus; Bais et al. (1994) for Channa punctatus, Dutta (1994) for Channa punctatus and Ali et. al. (2003) for Mastacembelidae. They categorized these fishes either as carnivore or omnivore. From the above findings it can be concluded that the different food groups varied monthly in their abundance in the gut contents of the fish where it showed some seasonal preference to certain food groups. The adult fish preferred to feed insects and crustaceans where the immature and juvenile fish preferred to feed on diatoms, copepods, cladocerans and rotifers.

\section{References}

Alam, M.J., Begum, M., Islam, M.A. \& Pal, H.K. 2006a. Induced spawning and fry production nona tengra, Mystus gulio (Hamilton.). Progress. Agric., 17 (1): 235-238.

Alam, M.J., Begum, M., Islam, M.A. \& Pal, H.K. 2006 b. Spawning behavior and induced breeding of an esturine cat fish, Mystus gulio (Ham.). Bangladesh J. Fish. Res., 10 (2): 101-109.

Ali, M.S., Rahman, M.M., Hossain, L. \& Mollah, M.F.A. 2003. Studies on the food habits of three species of Mastacembelidae. Bangladesh J. Fish. Res. 7 (1): 43-52.

Bais, V., Thakur, S. \& Agarwal, S.S. 1994. Food and feeding activity of Channa punctatus (Bloch). Freshwater Biol. 6: $247-251$.

Bhatt, V.S. 1971a. Studies on the biology of some freshwater fishes. Part V. Mystus vittatus (Bloch). J. Bombay Nat. Hist. Soc. 68 (3): 556-572.

Bhuiyan, A.S. 1988. The food and feeding habit of the fry of Cirrhina reba (Hamilton). Rajshahi University Studies, Part B. (17): 245-256.

Bhuiyan, A.S. \& Haque, M.S. 1985. The food and feeding habit of the fry of Glossogobius guiris (Ham-Buchanon) Gobidae: Perciforms from the river Padma. Bangladesh J. Aquaculture. 6-7 (1): 31-34.

Bhuiyan, A.S. \& Rahman, K. 1983. Food and seasonal pattern of feeding of the freshwater snake headed fish Channa gachua (Hamilton). BASS Proceeding of the $8^{\text {th }}$ Bangladesh Science conference, Dhaka.

Bisht, R.S. \& Das, S.M. 1981. Observation on aquatic insects as food of fishes and the predatory action of some aquatic insects on fish and fish food. J. Inland. Fish. Soc. 13 (2): 80-86

David, A. 1963. Fishery and Biology of the Schilbeid catfish, Pangasius pangasius (Ham.) and utility and propagation in culture ponds. Indian J. Fish. 10 (2): 521-600.

Dewan, S. \& Shaha, S.N. 1979. Food and feeding habits of Tilapia nilotica (L.) (Perciformes: Cichlidae). Bangladesh J. Zool. 7 (2): 75-80

Dutta, S.P.S. 1994. Food and feeding of Channa punctatus inhabiting Gadigarh Stream, Jammu, Freshwater Biol. 69: 333-336.

Homans, R.E.S. \& Vladykov, V.D. 1954. Relation between feeding and sexual cycle of the haddock. J. Fish. Res. Bd. Canada. II, 535-542.

Jhingran, V.G. 1997. Fish and Fishes of India. Hindustan Publishing Corporation (India). $3^{\text {rd }}$ edition. pp. xxiii+727.

Khan, M.S., Ambak, M.A. \& Mohsin, A.K.M. 1988. Food and feeding biology of a tropical freshwater catfish, 
Mystus nemurus C.\&V. with reference to its functional morphology. Indian J. Fish. 35 (2): 78-84.

Mustafa, G., Ahmed A.T.M. \& Islam, K.R. 1980. Food and feeding habit and fecundity of a freshwater perch, meni fish. Bangladesh J. Agril. Sci. 5 (4): 205-210

Needham, J.G. \& Needham, P.R. 1962. "Guide to the Study of Freshwater Biology". $5^{\text {th }}$ edition. Holden day Inc. San Francisco. 108 pp.

Pandian, T.J. 1966. Feeding and reproductive cycle of the fish Mystus gulio in the cooum backwaters, Madras. Indian J. Fish. 13 (182) XIII (1-2): 322-333.

Pantulu, V.R. 1961. Determination of age and growth of Mystus gulio (Ham.) by the use of pectoral spines, with observations on its biology and fishery in the Hooghly estuary. Proc. nat. Inst. Sci. India. 27: 198-225.

Pennak, R.W. 1953. "Freshwater Invertebrates of the United States” Ronald Press, New York. 769 pp.
Prescott, G.W.1962. "Algae of the Western Great Lakes Area” Wm. C. Brown Co., Pub., Dubuque, Lowa. $946 \mathrm{pp}$.

Reddy, Y.S. \& Rao, M.B. 1987. A note on the food of Mystus vittatus(Bloch) from the highly polluted Hussain Sagar lake, Hyderabad. Indian J. Fish. 34 (4): 484-487.

Sarker, P.K., Pal, H.K., Rahman, M.M. \& Rahman, M.M. 2002. Observation on the fecundity and gonado-somatic index of Mystus gulio in brackishwater of Bangladesh. Online J. Biol. Sci., 2(4): 235-237.

Thomas, J.D. 1966. On the biology of the catfish Clarias senegalensis in a man-made lake in the Gahnian Savanna with Particular reference to its feeding habits. J. Zool. 148: 476-514.

Ward, H.B. \& Whipple, G.C. 1959. Freshwater Biology. John Wiley and Sons, Inc., New York. 124 pp.

Manuscript received on 10.03.200,accepted on 23.07.2008 